${ }^{10}$ Be exposure age for sorted polygons in the Sudetes Mountains

$4{ }^{a}$ Charles University, Faculty of Science, Department of Physical Geography and Geoecology,

5 Prague, Czech Republic

$6 \quad$ b CEREGE CNRS Aix Marseille Univ., IRD, INRAE, Collège de France, Aix-en-Provence,

7 France

$8 \quad{ }^{\mathrm{c}}$ Academy of Sciences of the Czech Republic, Institute of Geophysics, Department of

9 Geothermics, Prague, Czech Republic

10 d The Krkonoše Mountains National Park Administration, Vrchlabí, Czech Republic

11 AsterTeam: Georges Aumaître, Didier Bourlès, Karim Keddadouche

$12 *$ Corresponding author. Tel.: +420 22195 1373. E-mail address: engel@ natur.cuni.cz.

\title{
14 Abstract
}

15 Patterned ground landforms represent the most common phenomenon of periglacial

16 environment and its large sorted forms belong to the few morphological indicators of former

17 permafrost distribution. Relic forms of patterned ground are widespread on high-elevated

18 surfaces in the central European uplands, providing the evidence of regional periglacial

19 conditions in the past. However, the timing of these landforms as well as their potential for

20 paleoclimate reconstructions, have remained unexplored. In this paper, we present ${ }^{10} \mathrm{Be}$ exposure ages from the large sorted polygons sampled at four sites in the Sudetes Mountains,

22 the highest part of the central European uplands. These results indicate that these landforms started to form at the end of MIS 3 and the main phase of their formation occurred between 30 and $20 \mathrm{ka}$. This research confirms the hypothesis of patterned ground formation within the Weichselian glacial (115ka-10ka ?) and suggests that earlier landforms are not preserved in the Sudetes. The recognised period of enhanced periglacial activity coincides with a prominent cold interval identified earlier in both regional and northern-hemispheric proxy records. 
Cryogenic sorted patterned ground refers to the arrangement of segregated fine and coarse material that form at the ground surface as a result of differential frost heave and buoyancydriven soil circulation. ${ }^{1}$ The resulting forms are more or less symmetric features among which circles and polygons are most common. The polygonal pattern reflects uneven penetration of freezing planes into the ground, displacement of clasts from concentrations of finer soil toward pattern margins, and lateral interaction of adjacent fine cells. ${ }^{2}$ Small-scaled circles and polygons $(<1 \mathrm{~m}$ in diameter) form in seasonally-frozen ground, but larger sorted forms are found only in areas underlain by permafrost. ${ }^{3}$ Relict forms of large sorted forms thus provide evidence for the former existence of permafrost and allow rough estimates of paleoclimatic conditions. ${ }^{4}$

The distribution of cryogenic sorted patterned ground has been frequently used for spatial reconstructions of periglacial environment during the cold stages of the Quaternary as their distinct pattern can be easily identified in the field and remotely sensed data. Moreover, dimensions of large (> $1 \mathrm{~m}$ wide) sorted forms of patterned ground indicate the thickness of former active-layer that corresponds to the depth of sorting and landform width. ${ }^{5}$ The paleoclimatic interpretation of patterned ground has been mostly considered limited because of the complex history of their formation and the possible influence of non-climate-related local factors. ${ }^{6}$ However, large sorted forms indicate lack of a thick snow cover, frequent freeze-thaw cycles, and air temperature thresholds required for differential sorting and frostheave. ${ }^{7}$ Nowadays, large sorted forms of patterned ground are active in the permafrost areas with mean annual air temperature (MAAT) lower than $-6{ }^{\circ} \mathrm{C}$ to $-3{ }^{\circ} \mathrm{C} .{ }^{8,9}$ Hence, these landforms can, when constrained by geochronological data, provide insights into Quaternary climatic conditions.

Unfortunately, there is still no robust approach for the dating of patterned ground, despite the recent advances in geochronology. The main problem for dating these structures results from the complex history of their formation as they can develop over a short/long time span and/or during multiple cold events. ${ }^{10}$ Large sorted polygons are products of recurrent freezing and thawing of the active layer, which causes upward movements of coarse clasts from the permafrost table and their subsequent migration towards the margins of the polygons. ${ }^{11,12}$

Under prolonged freeze-thaw conditions, the boulders forming the margins may be tilted due 
61 to lateral squeezing of adjacent polygons. ${ }^{13}$ Although this process can shorten the exposure

62 age of the boulders it still represents the period of polygon formation. If the frequency of freeze-thaw cycles drops back to the non-permafrost conditions, the supply of clasts via frost heave and lateral sorting ceases and large boulders at the margin of the polygons stabilize, attesting to the last time of their activity. Smaller pattern may eventually form in the centre of the inactive polygons at a later time if environmental conditions become suitable. ${ }^{3}$

Since the 1990s, radiocarbon, luminescence and terrestrial in situ-produced cosmogenic nuclides (TCN) dating methods have been applied on patterned-ground forms to determine their ages. Radiocarbon ages were reported mostly for non-sorted patterned ground, especially earth hummocks, rich in organics. ${ }^{14}$ Only few radiocarbon data were obtained for sorted patterned ground $^{15-17}$ that usually contains a small amount of organic material. Moreover, this material may have formed earlier or later than the landform itself. ${ }^{16}$ Thermoluminescence and optically stimulated luminescence (OSL) dating has been used for the dating of non-sorted circles, stripes and polygons ${ }^{18-20}$ but a successful application remains challenging. ${ }^{21}$ Apart from the issues related to the polycyclic nature of these features, ${ }^{19}$ the possible incorporation of incompletely bleached grains, and fluctuations of the water content after sedimentation of the material complicates the interpretation of the luminescence data. ${ }^{22}$ The application of TCN in the dating of patterned ground is still rare. The method has only been used to estimate the timing of poorly sorted patterns based on the dating of underlying rock glaciers. ${ }^{23,24}$ and to obtain Schmidt-hammer exposure ages for sorted circles and stripes. ${ }^{6,25}$ The most frequent applications of TCN in the periglacial landscape include the determination of "periglacial trimlines, ${ }^{26}$ the timing of rock glaciers ${ }^{27}$ and boulder fields. ${ }^{28}$

In this paper, we aim at constraining the timing of sorted polygons in the Sudetes Mountains, the highest section of the central European uplands. This region is characterized by large surfaces of low relief above $1200 \mathrm{~m}$ a.s.l. (referred to as summit planation surfaces in this paper $)^{29}$ with well-developed periglacial landforms. Among these landforms, sorted patterned ground phenomena were recognised first because of their distinctive morphology and widespread distribution. ${ }^{30}$ An earlier hypothesis relates their origin with past glacial cycles and attributes most of the preserved forms to the culmination phase of the last glacial period. ${ }^{31}$ An alternative view suggests that most patterned ground in the Sudetes formed during the Lateglacial period. ${ }^{32}$ In either case, the chronology of these landforms and paleoclimatic conditions during the period of their formation remain uncertain. In order to constrain the timing of the formation of large sorted polygons and to infer paleoclimate conditions for this 
period we have analysed their distribution and morphology in the Krkonoše and Hrubý Jeseník Mountains, the highest parts of the Sudetes . 24 new ${ }^{10} \mathrm{Be}$ surface exposure ages from four sorted polygon assemblages were produced and., , the established chronology was compared with a local set of exposure ages reported for glacial and periglacial landforms and with the existing records of paleoenvironmental conditions in central Europe.

\section{Study area}

The Sudetes Mountains on the Czech/Polish boundary represent a $340 \mathrm{~km}$ long eastern section of the central European uplands that stretch along $50^{\circ} \mathrm{N}$. During the Quaternary glaciations, the Sudetes Mountains were located within the periglacial zone between the Fennoscandian ice sheet and ice cap over the Alps (Fig. 1, inset). The width of the zone ranged from $430 \mathrm{~km}$ in the Last Glacial Maximum (LGM) to more than $1300 \mathrm{~km}$ during the Middle Weichselian interstadial. Periglacial processes and loess deposition dominated the development of this zone over cold stadial episodes. An extensive loess deposition belt was formed in the northern part of the zone while a more scattered loess cover arose at the southern front of the Sudetes Mountains below $450 \mathrm{~m}$ a.s.1. ${ }^{35}$ Periglacial processes have been most intense on summit planation surfaces where the annual precipitations were estimated to range from 500 to 700 mm during the $\mathrm{LGM}^{36}$ and the MAAT was 7 to $10^{\circ} \mathrm{C}$ lower than at present. ${ }^{37}$ During the last glaciation, cirque and valley glaciers modified the central part of the ranges ${ }^{38}$ but periglacial landscape has retained larger extent.

The Sudetes Mountains are located in a transitional zone between areas dominated by the oceanic climate and the continental type regimes. The precipitation on summit planation surfaces decreases from the Krkonoše Mountains in the western part of the Sudetes Mountains (>1500 mm per year) ${ }^{39}$ to the Hrubý Jeseník Mountains near the eastern margin of the range (1200-1300 mm per year). ${ }^{40}$ The MAAT for the period $1961-1990$ ranged from $0.4^{\circ} \mathrm{C}$ at the Sněžka weather station (1603 m a.s.l.) in the Krkonoše Mountains and $0.9^{\circ} \mathrm{C}$ at the Praděd station (1492 m a.s.1.) in the Hrubý Jeseník Mts. to approximately $3{ }^{\circ} \mathrm{C}$ at an elevation of 1200 m a.s.1. ${ }^{41}$ Westerly winds prevail within the Sudetes Mountains transporting snow from the summit plateaus to leeward slopes. ${ }^{42}$

The Krkonoše Mountains comprise a WNW-ESE oriented main (Silesian) ridge built of the mid-Carboniferous granites ( $320-315 \mathrm{Ma})$ and a parallel southern (Bohemian) ridge at the contact between the plutonic complex and Neoproterozoic to Lower Palaeozoic metamorphic rocks. ${ }^{43}$ The ridges delimit the relics of high-elevated (1350-1500 $\mathrm{m}$ a.s.1.) ${ }^{44}$ planation 
surfaces (Fig. 1a and 2a) formed as a result of slow weathering and long-term denudation that probably started around 75 Ma. ${ }^{46}$ The Hrubý Jeseník Mountains consist of Keprník and Desná Domes oriented approximately NE-SW (Fig. 1b). Both domes are built by a Cadomian crystalline basement imbricated with metamorphosed Devonian volcano sedimentary complexes. ${ }^{47}$ The domes have well-developed summit planation surfaces at 1300-1460 m a.s.1., ${ }^{48}$ which are more extensive in the southern part of the Desná Dome (Fig. 3a). Planation surfaces in both the Krkonoše and Hrubý Jeseník Mountains are covered with periglacial deposits among which sorted forms of patterned ground prevail. ${ }^{45}$

The four studied sites are located in high-elevated parts of the Sudetes Mountains. Vysoké Kolo (1509 m a.s.l.), the highest granite elevation in the western Krkonoše Mountains, and quartzite-dominated Luční hora (1555 m a.s.1.) on the Bohemian Ridge (Fig. 1a) represent the highest summit planation surface in the Sudetes Mountains. Břidličná hora (1358 m a.s.l.) and Větrná louka (1250-1270 m a.s.l.) consist of phyllites and represent the southern part of the Hrubý Jeseník Mountains (Fig. 1b). Břidličná hora belongs to the highest elevations on the Desná Dome whereas Větrná louka is located on a lowered planation surface on a side ridge (Fig. 3). Products of in situ weathering dominate at all sites and small sections of exposed bedrock are present only on Luční hora. All sites except Větrná louka are located in the zone of limited vegetation above the timberline (Fig. 1 and 3e).

\section{Methods}

\subsection{Morphological analyses and boulder sampling}

We selected four study sites with the best-developed and undisturbed sorted polygons in the Sudetes Mountains for morphological analyses and ${ }^{10} \mathrm{Be}$ sampling. The length, width and height of the 81 sorted polygons were measured at these sites. The height is defined as the maximum vertical distance between the lowest point at the polygon border and the highest point at its updomed centre. ${ }^{49}$ Between-site differences in the height and width of the sorted polygons were assessed by a one-way analysis of variance (ANOVA), and tested using an Ftest at the significance level $p=0.05$. The length of the sorted polygons was excluded from the ANOVA analyses because this parameter can relate to the surface inclination and thus it can reflect other factors, such as solifluction. ${ }^{50}$ The width of the polygons was used to roughly estimate the thickness of the past active layer based on the regression equation (Fig. 4) for a set of published paired data. ${ }^{4,5,9,51-67}$ 
The sorting depth for polygons and thickness of weathered rock at study sites were determined using electrical resistivity tomography. Soundings were carried out across the given polygon assemblage between the nearest edges of the given summit flat. The method was applied at multiple four-electrode arrays with 2-m spacing between the electrodes using the Wenner-Schlumberger measuring method. ${ }^{68}$ The obtained apparent resistivity data were subjected to the geophysical inversion procedure (L1-norm) in RES2DINV software (Geotomo, Malaysia).

We sampled six boulders per site to increase the possibility of deriving a robust ${ }^{10} \mathrm{Be}$ chronology. At each site, we collected samples from two to three individual sorted polygons. The samples were collected preferentially from the largest upright boulders located in a border of a sampled undisturbed polygon. This approach limits the possibility of the tilting of boulders after their active upfreezing/frost heaving and reduces the effects of snow and vegetation cover. ${ }^{69}$ The samples were collected using a chisel and a hammer; the samples were taken from the sampled surface to the depth of 2 to $7 \mathrm{~cm}$. The dip/orientation of the sampled surfaces was measured with a clinometer and a compass and their location/altitude was determined with GPS. The characteristics of sampled boulders and study sites are given in Table 1 and 2, respectively.

\section{$3.2{ }^{10}$ Be methodology}

The samples were crushed, sieved and cleaned with a mixture of $\mathrm{HCl}$ and $\mathrm{H}_{2} \mathrm{SiF}_{6}$. The extraction method for ${ }^{10} \mathrm{Be}^{70,71}$ involves isolation and purification of quartz and elimination of atmospheric ${ }^{10} \mathrm{Be}$. A weighed amount $(\sim 0.1 \mathrm{~g})$ of a $3025 \mathrm{ppm}$ solution of ${ }^{9} \mathrm{Be}$ was added to the decontaminated quartz. Beryllium was subsequently separated from the solution by successive anionic and cationic resin extraction and precipitation. The final precipitates were dried and heated at $800{ }^{\circ} \mathrm{C}$ to obtain $\mathrm{BeO}$, and finally mixed with niobium powder prior to the measurements, which were performed at the French Accelerator Mass Spectrometry (AMS) National Facility ASTER (CEREGE, Aix en Provence).

The beryllium data were calibrated directly against the STD-11 beryllium standard using a ${ }^{10} \mathrm{Be} /{ }^{9} \mathrm{Be}$ ratio of $1.191 \pm 0.013 \cdot 10^{-11} \cdot{ }^{72}$ Age uncertainties include an external AMS uncertainty of $0.5 \%,{ }^{73}$ blank correction and $1 \sigma$ uncertainties. The ${ }^{10} \mathrm{Be} /{ }^{9} \mathrm{Be}$ measured blank ratio associated to the samples presented in this paper is $3.618 \cdot 10^{-15}$. A density of $2.5 \mathrm{~g} \mathrm{~cm}^{-3}$ was used for all samples. A sea-level, high-latitude spallation production of $4.01 \pm 0.18$ at $\mathrm{g}^{-}$ ${ }^{1} \cdot \mathrm{yr}^{-1}{ }^{74}$ was used and scaled for latitude and elevation using Stone ${ }^{75}$ scaling scheme. The 
surface production rates were also corrected for the local slope and topographic shielding due to the surrounding terrain. ${ }^{76}$ Shielding from snow was estimated using an average snow density of $0.3 \mathrm{~g} \cdot \mathrm{cm}^{-3}$ and an estimated snow thickness and duration at sample sites. ${ }^{77}$ These values were derived from the mean thickness and duration of snow cover during the years 1961-1990 at 14 weather stations (445-1410 m a.s.1.) in the Sudetes Mountains. As the snow cover is unevenly distributed and its variation since the exposure of sampled surfaces is unknown, the real effect of snow shielding remains uncertain. However, most of samples were extracted from windswept sites without vegetation and we therefore suspect that temporal variation in snowfall has had a minor effect on snow conditions at these sites.

${ }^{10} \mathrm{Be}$ concentrations were modelled using the equation:

$$
C_{(x, \varepsilon, t)}=\frac{P_{\text {spall. }}}{\frac{\varepsilon}{\Lambda_{n}}+\lambda} \cdot e^{-\frac{x}{\Lambda_{n}}}\left[1-\exp \left\{-t\left(\frac{\varepsilon}{\Lambda_{n}}+\lambda\right)\right\}\right]+\frac{\mathrm{P}_{\mu}}{\frac{\varepsilon}{\Lambda_{\mu}}+\lambda} \cdot e^{-\frac{x}{\Lambda_{\mu}}}\left[1-\exp \left\{-t\left(\frac{\varepsilon}{\Lambda_{\mu}}+\lambda\right)\right\}\right]
$$

where $C_{(x, \varepsilon, t)}$ is the nuclide concentration as a function of depth $x\left(\mathrm{~g} \cdot \mathrm{cm}^{-2}\right), \varepsilon$ the denudation rate $\left(\mathrm{g} \cdot \mathrm{cm}^{-2} \cdot \mathrm{yr}^{-1}\right), t$ the exposure time $(\mathrm{yr})$ and $\lambda$ the radioactive decay constant $\left(\mathrm{yr}^{-1}\right) . P_{\text {spall }}$ and $P_{\mu}$ are the relative production rates due to neutrons and muons, respectively. $\Lambda_{\mathrm{n}}$ and $\Lambda_{\mu}$ are the effective apparent attenuation lengths $\left(\mathrm{g} \cdot \mathrm{cm}^{-2}\right)$, for neutrons and muons, respectively. The muon scheme follows Braucher et al. ${ }^{78}$

To estimate minimum exposure ages, denudation was set to zero whereas the exposure time was supposed to be infinite to infer maximum denudation rates. In that latter case, it is possible estimating the time (integration time, noted $T_{i n t}$.) needed to reach the steady state concentration using a modified equation based on the approach of $\mathrm{Lal}^{79}$ which do not consider muon contributions; the modified equation is:

$$
T_{\text {int }}=\frac{\% \text { Pspall }}{\frac{\operatorname{Ln}(2)}{1387000}+\frac{\epsilon}{160}}+\frac{\% \text { P SSlow }}{\frac{\operatorname{Ln}(2)}{1387000}+\frac{\epsilon}{1500}}+\frac{\% \text { PFast }}{\frac{L N(2)}{1387000}+\frac{\epsilon}{4320}}
$$


where $\% P$ spall, $\% P \mu$ Slow and $\% P \mu F a s t$ are the percentage contributions of neutrons, Slow and Fast muons respectively in the total production and 160, 1500 and $4320 \mathrm{~g} \cdot \mathrm{cm}^{-2}$ their respective attenuation lengths.

\subsection{Data treatment}

We assess the distribution of exposure ages obtained at individual sample sites, compare the arithmetic means and standard deviations calculated for four age populations, and interpret the chronological data with exposure ages reported from the Sudetes Mountains in previous studies.

We first analyse the scatter in exposure-age data sets for each sample site because the age distribution reflects the exposure history of sampled surfaces and indicates main sources of geological uncertainties - cosmogenic-nuclide inheritance and disturbance of boulders after emplacement. ${ }^{80}$ Among a group of sample, a sample with inherited ${ }^{10} \mathrm{Be}$ can be identified by a higher concentration yielding to older age than the mean of the remaining ages. By contrast,a significant younger age may indicate incomplete exposure of the sampled boulder. The distribution of the exposure ages obtained for the given sample site and scatter in the age groups were approximated using the reduced chi-square statistics $\left(\chi_{R}^{2}\right)$ and a standard deviation (SD) to the arithmetic mean exposure age ratio. Following the procedure presented by Blomdin et al., ${ }^{81}$ age groups that have $\chi_{R}^{2} \leq 2$ are classified as well-clustered, groups that show $\chi_{R}^{2}>2$ but $\mathrm{SD} \leq 15 \%$ of the mean exposure age are considered as moderately-clustered, and groups that show $\chi_{R}^{2}>2$ and SD $>15 \%$ of the mean age are designated as poorlyclustered.

Subsequently, we calculated an arithmetic mean and standard deviations (1s) for each site, compare these values, and assessed their relevance for regional estimate of polygon chronology. When the age ranges of two or more sample sites overlap within their analytical uncertainties we consider them representative as a regional interval of the sorted polygon formation. We compare this interval with regional glaciation chronology and we interpret the data with respect to exposure ages reported for periglacial landforms in the Sudetes Mountains. ${ }^{82,83}$ An apparent age that differs significantly from the resulting age range is excluded from chronological consideration. A number of factors can cause apparent exposure ages of the sampled landforms and these are discussed in section 5.1. 
The sorted polygons occur on flat or gently inclined surfaces (Fig. 2bcde, 3bcde) with the median slope around $3^{\circ}$ (Table 2). The length and width of the polygons range between $2.5-$ $10.5 \mathrm{~m}$ and 2.1-6.4 m, respectively (Table 3). The sorted polygons on Vysoké Kolo (VK) have the largest average length $(6.97 \mathrm{~m})$, followed by the polygons on Břidličná hora (BR) and Větrná louka (VL), while the patterns with the smallest average length $(3.67 \mathrm{~m})$ lie on Luční hora (LH). The polygons on Luční hora have significantly smaller width (Fig. 5) than the polygons at other study sites (i.e. LH $v s \mathrm{VK}: \mathrm{F}(1.41)=26.643, p=0.00001$; LH $v s$ BR: $\mathrm{F}(1.62)=19.491, p=0.00004 ; \mathrm{LH} v s \mathrm{VL}: \mathrm{F}(1.38)=14.576, p=0.00048)$. The sorted polygons with the largest average height lie on Větrná louka (Table 3, Fig. 5), which significantly differs from other study sites (i.e. VL $v s \mathrm{LH}: \mathrm{F}(1.38)=260.24 ; p<0.00001 \mathrm{VL}$ vs $\mathrm{VK}: \mathrm{F}(1.17)=71.698, p<0.00001$; VL $v s \mathrm{BR}: \mathrm{F}(1.38)=201.41 ; p<0.00001)$.

\subsection{Regolith thickness}

The high electrical-resistivity zones of more than ca. 60,000 $\Omega \cdot \mathrm{m}$ at the Vysoké Kolo, Luční hora, and Břidličná hora sites (Fig. 6a, 6b and 6c) are associated with the presence of air-filled debris. By contrast, the resistivity of the weathering mantle at Větrná louka is lower (Fig. 6d) because this site lies below the alpine timberline and is covered with a thick top soil layer, which supports the cavities between the boulders with fine-grained materials. In addition, the quartzite vein crossing the Větrná louka site causes a slight bedrock protrusion, while at other locations the bedrock is mostly parallel to the ground surface. The regolith at the Vysoké Kolo, Břidličná hora, and Větrná louka sites is two to three times thicker than on Luční hora where regolith/bedrock transition is around $2 \mathrm{~m}$ (Fig. 6b) below the ground surface. The small depth of bedrock at this site is constrained by the nearest cryoplanation terrace located $3 \mathrm{~m}$ lower.

\subsection{Exposure ages}

For all studied sites, surface exposure age are scattered (Table 1) and age groups are poorly clustered (Table 2). Exposure ages obtained for the patterned ground on Vysoké Kolo yield a mean age of $25.4 \pm 1.9 \mathrm{ka}$ and an oldest age of $30.3 \pm 1.1 \mathrm{ka}$. This boulder group has the smallest scatter and ages range from 19 to $30 \mathrm{ka}$. Boulder group from the sorted polygons on Luční hora have a mean age of $53.6 \pm 11.4 \mathrm{ka}$. The exposure ages from this summit flat show 
the largest scatter of all the study sites, ranging from $91.3 \pm 2.8$ ka to $9.0 \pm 5.6 \mathrm{ka}$. Exposure ages obtained on Břidličná hora yield a mean age of $28.0 \pm 1.0 \mathrm{ka}$ and a maximum age of 38.1 $\pm 1.6 \mathrm{ka}$. This oldest age is significantly older than the calculated mean age but remaining ages fall within a narrow range of 23-29 ka. Boulder group from Větrná has a mean exposure age of $24.3 \pm 4.8 \mathrm{ka}$ and an oldest age of $47.9 \pm 1.4 \mathrm{ka}$ that is an obvious outlier according to the $\chi 2$ criterion.

\subsection{Steady-state denudation rates}

Considering the possibility that all samples have reached the denudational steady state (time being consider as infinite in eq. 1 ), the measured ${ }^{10} \mathrm{Be}$ concentrations may help to estimate maximum steady state denudation rates. The highest values were obtained for the Větrná louka site where all but one (VL2) samples yield maximum steady state denudation rates ranging from 30 to $43 \mathrm{~mm} / \mathrm{ka}$. The denudation rate of $79.3 \pm 49.4 \mathrm{~mm} / \mathrm{ka}$ was calculated for the sample LH4 but large uncertainty precludes robust interpretation of this value. Moreover, other samples from the Luční hora site yield lower denudation rates than samples collected at the remaining study sites (Table 1 ).

\section{Discussion}

\subsection{Exposure age interpretation and uncertainties}

The scatter in age groups indicates that some sampled boulders experienced complex exposure history or post-exposure disturbance. An observed distribution of six exposure ages is affected by the presence of one or two underestimated ages and one overestimated age at all but one sample site. A significantly older sample age than the mean exposure age calculated for the landform results from cosmogenic-nuclide inheritance. ${ }^{84}$ The most probable reason for inherited nuclide concentration in boulders that form the margins of sorted polygons is their initial position at shallow subsurface depth affected by cosmic-ray flux. The cosmogenicnuclide production decreases rapidly with depth and it is largely attenuated below $\sim 1 \mathrm{~m}$ depth. ${ }^{85}$ Boulders located below fine-grained regolith in this thin subsurface zone (Fig. 8B) contain inherited ${ }^{10} \mathrm{Be}$ from a period prior to the frost-heave event and they will show apparently older age than boulders with zero inherited nuclide concentration frost-heaved from greater depths. An alternative scenario that could lead to inheritance deals with the repeated phase of polygon formation and emplacement of boulders that had experienced previous exposure at the margins of former polygons. However, this scenario is less probable 
as most of these boulders disintegrate over the period between two subsequent cold stages and similar or higher freeze-thaw activity would be necessary to rearrange existing polygons.

The presence of apparently younger boulders in the margins of sorted polygon could be attributed to post-exposure tilting of sampled surfaces ${ }^{87}$ rather than to surface erosion or disintegration because only boulders without signs of erosion or fractures were sampled. The post-exposure shielding of sample sites by ice or snow cover can be excluded from this consideration too. Glaciers were confined to cirques and valleys during the $\mathrm{LGM}^{82}$ and hypothetic plateau ice fields were suggested to cover high elevations except for wind-swept top of the ridges. ${ }^{88}$ The presence of permanent snow cover is rather improbable because of reduced precipitation $(25-75 \%)$ in cold stages ${ }^{37,89}$ and more effective deflation by enhanced winds. ${ }^{36}$ Finally, the younger age of particular boulders cannot result from mass-shielding by vegetation and/or soil cover that is evenly spread over the sample sites.

The obtained chronological data suggest that the large sorted polygons in the Sudetes Mountains developed during the last glacial period. Considering relatively small areal extent of the Sudetes Mountains, narrow elevation range of sample sites, and similar topographic and climate conditions at these sites, the period of formation of large sorted polygons could have occurred around the same time throughout the Sudetes. However, the summed probability density distribution of the obtained ${ }^{10} \mathrm{Be}$ exposure ages is bimodal with a main peak centred on $25 \mathrm{ka}$ and a minor increase around $64 \mathrm{ka}$ (Fig. 7, black curve). The main peak indicates that the formation of sorted polygon started no later than $30 \mathrm{ka}$, reached a climax around 25 $\mathrm{ka}$, and ceased after $18 \mathrm{ka}$. The second modelled peak reflects high levels of in situ produced ${ }^{10} \mathrm{Be}$ in samples from the Luční hora site. These samples seem to be affected by inheritance as indicated by apparently older mean age $(53.6 \pm 11.4 \mathrm{ka})$ compared to other sites $(24.3 \pm 4.8 \mathrm{ka}$ to $27.9 \pm 2.3 \mathrm{ka}$ ). The possible reasons for the inheritance are discussed below. The reduced dataset $(n=18)$ without exposure ages from Luční hora yields the mean exposure age of 25.0 $\pm 0.4 \mathrm{ka}$ (Fig. 7, grey curve).

The largest scatter in the age group from Luční hora confirms that inheritance must be considered at this site. The exposure age of $91.3 \pm 2.8 \mathrm{ka}$ is the oldest within the whole dataset, and the apparent mean age is significantly older than the timing of the established main phase of polygon formation. The inheritance at this site may be tentatively attributed to the quartzite bedrock and poorly developed regolith cover. Despite the presence of surface features caused by differential weathering, the quartzite is more resistant to physical 
weathering and erosion than granite and phyllite at other sample sites. The hardness of the massive quartzite and considerably reduced surface lowering of landforms built by this rock were reported from many regions including the Sudetes Mountains. ${ }^{32,90}$ The effect of the rock hardness on an exposure age was observed by Guido et al., ${ }^{91}$ who reported a significantly older exposure age $(30.1 \mathrm{ka})$ for a quartzite knoll compared to ages from other rock types (12.3 to $17.1 \mathrm{ka})$.

The hardness of the quartzite exerts control on the rate of weathering that is much lower compared to weathering rate of granite and phyllite bedrock. As a result, a thin layer of regolith has formed on Luční hora where bedrock lies only around $2 \mathrm{~m}$ below the ground surface. By contrast, 4 to $9 \mathrm{~m}$ of weathered rock cover the bedrock at the remaining study sites (Fig. 6). The sorting depth corresponds with the thickness of regolith cover ranging from less than $0.5 \mathrm{~m}$ on Luční hora to around $1.4 \mathrm{~m}$ on Břidličná hora. ${ }^{92,}{ }^{93}$ Considering the mean attenuation path length of neutrons in rocks ${ }^{84}$ and the depth of boulders $(>0.5 \mathrm{~m})$ before the initiation of polygon formation on Luční hora, the relatively small boulders at this site contain a substantial inherited nuclide component. By contrast, larger boulders that form polygons at other sites (Table 2) have significantly less inherited ${ }^{10} \mathrm{Be}$ as these were frost heaved from the depth of more than $1.4 \mathrm{~m}$.

The high fraction of boulder ages with inheritance indicate that exposure dating should be applied on polygon boulders with caution. The age uncertainty resulting from the effects of vegetation and snow cover shielding seems to be of minor importance. All sample sites except Větrná louka are located above the timberline in the zone of limited vegetation and snow cover that is effectively transported from the summit flats by the prevailing westerly winds. ${ }^{42}$ The timberline increased to its current position in the Sudetes Mountains during the early Holocene, and forest has covered Větrná louka site at least over the last $8 \mathrm{ka} .{ }^{94}$ Considering that boreal forest can reduce the cosmic ray flux by $2.3 \pm 0.6 \%,{ }^{95}$ the estimated timing of polygons at this site could be underestimated only by a few hundred years.

\subsection{Paleoenvironmental implications}

The exposure ages indicate that large sorted polygons in the Sudetes Mountains formed during the Upper Pleniglacial $(34.8-14.7 \mathrm{ka})^{96}$ after a period of unstable climate in the second part of MIS 3. ${ }^{97,98}$ The onset of the polygon formation corresponds to the Greenland substadial GS-5.1 (30.6-28.9 ka) ${ }^{99}$ and the main activity of these landforms reflects extremely cold and relatively wet conditions in the Northern Hemisphere during the stadial GS-3 (27.5- 
$23.3 \mathrm{ka}){ }^{100}$ The period of polygon formation overlaps with the range of 30-24 ka (Fig. 9), which is considered as the period of the maximum extension of permafrost (Last Permafrost Maximum, LPM) ${ }^{111}$ in Western Europe during the last glacial cycle. ${ }^{102}$ The timing of the dated polygons is in line with the two (35-31 and 22-20 ka) out of four main phases of periglacial activity in Britain lowlands, ${ }^{22}$ and corresponds to some phases $(30.0 \pm 2.5,24.0 \pm$ 1.1 and $20.7 \pm 0.7 \mathrm{ka}$ ) of ice-wedge activity in France. ${ }^{102}$

The onset of differential frost heave in the Sudetes coincides with the pre-LGM period of periglacial conditions indicated recently by ${ }^{10} \mathrm{Be}$ exposure ages (Fig. 9). The exposure age of $36.5 \pm 2.1 \mathrm{ka}$ and $29.7 \pm 2.1 \mathrm{ka}$ reported for a summit tor and ploughing block, respectively, delimit the interval of bedrock disintegration and enhanced solifluction in the Krkonoše Mountains (Fig. 9) ${ }^{82}$ Four exposure ages $(84.3 \pm 3.8$ to $26.8 \pm 2.6 \mathrm{ka})$ retrieved recently for a block slope adjacent to the Větrná louka site constrain the pre-LGM timing of cold environments in the Hrubý Jeseník Mountains. ${ }^{83}$ At that time, permafrost reached its maximum extent and thickness (220-250 m) as indicated by the subsurface post-cryogenic structures near the eastern boundary of the Sudetes Mountains, ${ }^{112}$ the model-based estimates ${ }^{36}$ and the cryogenic cave carbonates. ${ }^{113}$ The size of polygons dated in this study implies activelayer thickness of $0.9-1.6 \mathrm{~m}$. This range is consistent with the summer thawing to the depth of 1 m suggested by $\mathrm{Jahn}^{114}$ for LGM interval.

The occurrence of sorted polygons indicates cold conditions and lack of thick snow cover on the upper slopes of the Sudetes Mountains between 30 and $18 \mathrm{ka}$. Considering the most respected temperature threshold for the sorted polygon formation, the MAAT was lower than $-4{ }^{\circ} \mathrm{C} .{ }^{9}$ The derived palaeotemperature represents maximal value for elevation range of 1210 $1270 \mathrm{~m}$ a.s.l. where dated polygons are preserved at Větrná louka site. Assuming the nearsurface lapse rate in the lower troposphere $(0.65 \mathrm{~K} / 100 \mathrm{~m})$, the MAAT on the summit flats around $1550 \mathrm{~m}$ a.s.l. was probably lower than $-6^{\circ} \mathrm{C}$. The estimated temperature range is higher than the MAAT estimates for LGM that vary between -8 and $-10{ }^{\circ} \mathrm{C} .{ }^{37,115}$ However, the palaeotemperatures derived in this study must be regarded as maximal thresholds only because sorted polygons are also found at lower elevations within the Sudetes Mountains.

Regional amelioration of the climate after around $18 \mathrm{ka}^{101}$ led to the gradual degradation of permafrost in the Sudetes Mountains. ${ }^{36}$ The intensity of frost action decreased allowing only for cryoturbation, solifluction and limited sorting of fine-grained covers. ${ }^{116}$ The periglacial activity increased again at the end of the Lateglacial period when the climate cooled and 
permafrost re-aggraded. ${ }^{101,117}$ The exposure ages reported for moraines $(13.5 \pm 0.5$ to $12.9 \pm$ $0.7 \mathrm{ka}$ ) and pronival ramparts (13.8 $\pm 0.4 \mathrm{ka})$ in the Krkonoše Mountains indicate glacier readvance and enhanced frost action (Fig. 9). ${ }^{82}$ At that time, frost sorting and solifluction were probably reactivated. ${ }^{117}$ Small sorted patterns observed in the large dated polygons on Luční hora summit flat may be tentatively attributed to that period though their later formation cannot be excluded. ${ }^{49}$ During the Holocene, the frost action has been limited to cryoturbation, solifluction and sorting of sandy covers in deflation areas with thin snow cover. ${ }^{50}$

\subsection{Summit flat denudation}

The observed differences in the maximum steady state denudation rates between the sample sites may reflect varying topography and bedrock conditions that control the intensity of surface processes on summit planation surfaces. The denudation rates $<20 \mathrm{~mm} / \mathrm{ka}$ obtained for the Luční hora site represent the highest summit planation surface in the Sudetes Mountains underlain by quartzite (Table 2). Well-preserved morphology and small elongation of the sorted polygons on this near-horizontal site indicate low rate of weathering and slope processes. Higher values of denudation rates inferred for Vysoké Kolo and Břidličná hora are consistent with less resistant bedrock (granite and phyllite) and more intense surface transport. The latter assumption is supported by the lower values of width/length index calculated for the preserved sorted polygons (Table 3 ). The highest denudation rates ( 40 mm/ka) were obtained for the Větrná louka site, which represents a lowered planation surface on a side ridge build by phyllites.

The observed denudation rates are comparable to the values derived from cosmogenic nuclides for bedrock outcrops in mid-latitude mountain regions. The low values determined for the highest planation surface in the Krkonoše Mountains correspond with the denudation rates reported for summit flats in Western U.S. mountain ranges $(2-19 \mathrm{~mm} / \mathrm{ka}),{ }^{119}$ ridgeline outcrops in the Appalachian Mountains ( 9 mm/ka), ${ }^{120}$ and arête-shaped ridges in the Pyrenees (9-21 mm/ka). ${ }^{121}$ The higher intensity of denudation determined for the lower planation surfaces in the Sudetes ranges is in line with the denudation rates reported for bedrock outcrops in the Rocky Mountains $(22-45 \mathrm{~mm} / \mathrm{ka})^{122,123}$ and flat ridges in the Pyrenees (30-40 mm/ka). ${ }^{121}$ This rate is also consistent with the catchment-wide denudation values derived from cosmogenic nuclides in the Vltava River terrace sequences south from the Sudetes Mountains (23-31 mm/ka). ${ }^{124}$ 
The maximum steady state denudation rates determined from ${ }^{10} \mathrm{Be}$ concentrations for the high-elevated sites provide new insights into the planation history of the Sudetes Mountains. Until now, the intensity of denudation was inferred only for time scales of $10^{7}$ to $10^{8}$ years based on the thermochronological data and sedimentary record. Three periods of accelerated denudation were suggested for the Sudetes over its post-Variscan history with the denudation rates as high as $300 \mathrm{~m} / \mathrm{Ma}$ during the early Permian, Early Triassic and Late Cretaceous. ${ }^{125}$ Significantly lower rates ranging from $\sim 16$ to $<0.1 \mathrm{~mm} / \mathrm{ka}$ with the mean of $\sim 7 \mathrm{~mm} / \mathrm{ka}$ were derived for the post-75 Ma period. ${ }^{46}$ However, the long-term denudation rates provide little evidence of surface lowering under glacial and interglacial conditions in the Quaternary. Our data indicate denudation rates on the order of tens of $\mathrm{mm} / \mathrm{ka}$ during the last glacial period. This suggests that the intensity of denudation increased during the Quaternary compared to Paleogene and Neogene periods. ${ }^{126}$

\section{Conclusions}

Surface exposure dating using cosmogenic ${ }^{10} \mathrm{Be}$ provides the first geochronological data for the sorted forms of patterned ground in central Europe. ${ }^{10} \mathrm{Be}$ exposure ages from the large sorted polygons at four sites in the Sudetes Mountains imply that these periglacial features started to form no later than $30 \mathrm{ka}$ and their activity decreased after $20 \mathrm{ka}$. The initiation of polygon formation is consistent with the most widespread events of thermal-contraction cracking during the LPM in central Europe, and with periods of enhanced periglacial activity in lowland Britain and France. The main phase of formation falls within the global LGM, matches the period of maximum glaciation and continuous permafrost distribution in European mountains, and correlates with the period of intense periglacial activity in the surrounding lowland areas.

The maximum steady state denudation rates calculated for the sample sites are on the order of tens of $\mathrm{mm} / \mathrm{ka}$ and corresponding integration times on the order of $10^{4}$ years. The observed denudation rates are comparable to those reported from summit flats and ridgeline outcrops in mid-latitude mountain regions and they constrain regional estimates for the temporal variability of the denudation.

The samples collected from the sorted polygons provide large scatter in exposure ages and significant age uncertainty. This scatter may result from the incorporation of boulders that are affected by inheritance or disturbances after their active upfreezing/frost heaving. The morphological evaluation of individual polygons and their assemblages at the study site is 
highly advisable as its results would allow for sample collections from suitable boulders and landforms. Although this evaluation reduces the possibility of sampling eroded or disturbed polygon, the complex history of earlier exposure and/or later reactivation cannot be fully excluded.

\section{Acknowledgements}

The research was supported by the Czech Science Foundation (project no. 17-21612S). The Administrations of the Krkonoše Mountains National Park and the Protected Landscape Area of Jeseníky are acknowledged for providing permissions to work in the protected areas. ASTER AMS national facility (CEREGE, Aix-en-Provence) is supported by the INSU/CNRS, the ANR through the "Projets thématiques d'excellence" program for the "Equipements d'excellence" ASTER-CEREGE action, IRD. The data that support the findings of this study are available from the corresponding author upon reasonable request. The authors are grateful for helpful and constructive comments from two anonymous referees.

\section{References}

1. Hallet B. Stone circles: form and soil kinematics. Philos T R Soc A, 2013;371:20120357.

2. Ballantyne CK. Patterned ground. In: Elias SA, Mock CJ, eds. Encyclopedia of Quaternary Science. $2^{\text {nd }}$ ed. Amsterdam: Elsevier; 2013:452-463.

3. Harris SA, Brouchkov A, Guodong C. Geocryology: Characteristics and Use of Frozen Ground and Permafrost Landforms. London: CRC Press; 2018.

4. Grab S. Characteristics and paleoenvironmental significance of relict sorted patterned ground, Drakensberg plateau, Southern Africa. Quaternary Sci Rev. 2002;21:17291744.

5. Uxa T, Mida P, Kř́žek M. The effect of climate on Morphology and Development of sorted circles and polygons. Permafrost Periglac. 2017;28:663-674.

6. Winkler S, Matthews JA, Mourne RW, Wilson P. Schmidt-hammer exposure ages from periglacial patterned ground (sorted circles) in Jotunheimen, Norway, and their interpretative problems. Geogr Ann A. 2016;98:265-285.

7. Matsuoka N. Climate and material controls on periglacial soil processes: towards improving periglacial climate indicators. Quat Res. 2011;75:356-365.

8. Goldthwait RP. Frost Sorted Patterned Ground: A Review. Quat Res. 1976;6:27-35.

9. D'Amico ME, Pintaldi E, Catoni M, Freppaz M, Bonifacio E. Pleistocene periglacial imprinting on polygenetic soils and paleosols in the SW Italian Alps. Catena. 2019;174:269-284.

10. Van Vliet-Lanoë B. Patterned ground and climate change. In: Pokrovsky OS, ed. Permafrost: distribution, composition and impacts on infrastructure and ecosystems. New York, NY: Nova Science Publishers; 2014:67-106. 
11. Matsuoka N, Abe M, Ijiri M. Differential frost heave and sorted patterned ground: Field measurements and a laboratory experiment. Geomorphology. 2003;52:73-85.

12. Peterson RA, Krantz WB. Differential frost heave model for patterned ground formation: Corroboration with observations along a North American arctic transect. $J$ Geophys Res-Biogeo. 2008;113:G03S04.

13. Kessler MA, Werner BT. Self-organization of sorted patterned ground. Science. 2003;299:380-383.

14. Van Vliet-Lanoë B, Seppälä M. Stratigraphy, age and formation of peaty earth hummocks (pounus), Finnish Lapland. Holocene. 2002;12:187-199.

15. Kling J. Relict sorted patterned ground in Rostu, Northernmost Sweden. Geogr Ann A. 1996;78:61-72.

16. Jeong G. Radiocarbon ages of sorted circles on King George Island, South Shetland Islands, West Antarctica. Antarct Sci. 2006;18:265-270.

17. Kelly M, Denton G, Hall B. Late Cenozoic paleoenvironment in southern Victoria Land, Antarctica, based on a polar glaciolacustrine deposit in western Victoria Valley. Geol Soc Am Bull. 2002;114:605-618.

18. Bateman MD. Thermoluminescence dating of the British coversand deposits. Quaternary Sci Rev. 1995;14:791-798.

19. Bateman MD, Hitchens S, Murton JB, Lee JR, Gibbard PL. The evolution of periglacial patterned ground in East Anglia, UK. J Quaternary Sci. 2014;29:301-317.

20. Fábián SÁ, Kovács J, Varga G, et al. Distribution of relict permafrost features in the Pannonian Basin, Hungary. Boreas. 2014;43:722-732.

21. Rittenour TM. Dates and Rates of Earth-Surface Processes Revealed using Luminescence Dating. Elements. 2018;14:21-26.

22. Bateman MD. Luminescence dating of periglacial sediments and structures. Boreas. 2008;37:574-588.

23. Marchant DR, Lewis AR, Phillips WM, et al. Formation of patterned ground and sublimation till over Miocene glacier ice in Beacon Valley, southern Victoria Land, Antarctica. Geol Soc Am Bull. 2002;114:718-730.

24. Levy J, Marchant D, Head J. Distribution and origin of patterned ground on Mullins Valley debris-covered glacier, Antarctica: The roles of ice flow and sublimation. Antarct Sci. 2006;18,385-397.

25. Winkler S, Matthews JA, Haselberger S, Hill JL, Mourne RW, Owen G, Wolson P. Schmidt-hammer exposure-age dating (SHD) of sorted stripes on Juvflye, Jotunheimen 
(central South Norway): Morphodynamic and palaeoclimatic implications.

Geomorphology. 2020;353:107014.

26. Ballantyne CK, Stone JO. Trimlines, blockfields and the vertical extent of the last ice sheet in southern Ireland. Boreas. 2015;44:277-287.

27. Andrés N, Gómez-Ortiz A, Fernández-Fernández JM, et al. Timing of deglaciation and rock glacier origin in the southeastern Pyrenees: a review and new data. Boreas. 2018;47:1050-1071.

28. Denn AR, Bierman PR, Zimmenrman SRH, Caffee MW, Corbett LB, Kirby E. Cosmogenic nuclides indicate that boulder fields are dynamic, ancient, multigenerational features. GSA Today. 2018;28:4-10.

29. Migon P, Lidmar-Bergström K. Weathering mantles and their significance for geomorphological evolution of central and northern Europe since the Mesozoic. Earth Sci Rev. 2001;56(1-4):285-324.

30. Högbom B. Über die geologische Bedeutung des Frostes. Bull Geol Inst. 1914;12:257390.

31. Sekyra J, Kociánová M, Štursová H, Dvořák IJ, Svoboda M. Frost phenomena in relationship to mountain pine. Opera Corcon. 2002;39:69-114.

32. Traczyk A, Migon P. Cold-climate landform patterns in the Sudetes. Effect of lithology, relief and glacial history. Acta U Carol Geogr Suppl. 2000;35:185-210.

33. Treml V, Migoń P. Controlling factors limiting timberline position and shifts in the Sudetes: A review. Geogr Pol. 2015;88:55-70.

34. Ehlers J, Gibbard PL, Hughes PD, eds. Quaternary Glaciations - Extent and Chronology: A Closer Look. Amsterdam: Elsevier; 2011.

35. Antoine P, Rousseau DR, Degeai JP, et al. High-resolution record of the environmental response to climatic variations during the last interglacial-glacial cycle in Central Europe: The loess-palaeosol sequence of Dolní Věstonice (Czech Republic). Quaternary Sci Rev. 2013;67:17-38.

36. Czudek T. Vývoj relief České republiky v kvartéru. Brno: Moravské zemské museum; 2005.

37. Heyman BM, Heyman J, Fickert T, Harbor JM. Paleo-climate of the central European uplands during the last glacial maximum based on glacier mass-balance modeling. Quaternary Res. 2013;79:49-54. 
38. Nývlt D, Engel Z, Tyráček J. Pleistocene glaciations of Czechia. In: Ehlers J, Gibbard PL, Hughes PD, eds. Quaternary Glaciations - Extent and Chronology: A Closer Look. Amsterdam: Elsevier; 2011:37-46.

39. Halásová $\mathrm{O}$, Hančarová E, Vašková I. Časová a prostorová variabilita vybraných klimatologických a hydrologických prvků na území Krkonoš za období 1961-2000. Opera Corcon. 2007;44:171-178.

40. Daniel M, Materna J, Honig V, et al. Vertical Distribution of the Tick Ixodes ricinus and Tick-borne Pathogens in the Northern Moravian Mountains Correlated with Climate Warming (Jeseníky Mts., Czech Republic). Cent Eur J Publ Heal. 2009;17:139-145.

41. Coufal L, Míková T, Langová P. Meteorologická data na území ČR za obdobi 1961-90. Praha: Český hydrometeorologický ústav; 1992.

42. Spusta V, Spusta V, Kociánová M. Ukládání sněhu na závětrných svazích české strany Krkonoš (tundrová zóna). Opera Corcon. 2003;40:87-104.

43. Žák J, Verner K, Sláma J, Kachlík V, Chlupáčová M. Multistage magma emplacement and progressive strain accumulation in the shallow-level Krkonoše-Jizera plutonic complex, Bohemian Massif. Tectonics. 2013;32:1493-1512.

44. Placek A, Migoń P, Żyszkowska W. Low-gradient surfaces in the Sudetes - insights from the digital elevation model. Univ Ostrav Acta Fac Rerum Nat Geogr Geol. 2007;237:94-110.

45. Křížek M, Krause D, Uxa T, Engel Z, Treml V, Traczyk A. Patterned ground above the alpine timberline in the High Sudetes, Central Europe. J Maps. 2019;15(2):563-569.

46. Danišík M, Migoń P, Kuhlemann J, Evans NJ, Dunkl I, Frisch W. Thermochronological constraints on the long-term erosional history of the Karkonosze Mts., central Europe. Geomorphology. 2010;117:78-89.

47. Janoušek V, Aichler J, Hanžl P, et al. Constraining genesis and geotectonic setting of metavolcanic complexes: A multidisciplinary study of the Devonian Vrbno Group (Hrubý Jeseník Mts., Czech Republic). Int J Earth Sci. 2014;103:455-483.

48. Křížek M. Periglacial Landforms of the Hrubý Jeseník Mountains In: Pánek T, Hradecký J, eds. Landscapes and Landforms of the Czech Republic. Cham: Springer; 2016:277-289.

49. Kř́žžek M, Uxa T. Morphology, Sorting and Microclimates of Relict Sorted Polygons, Krkonoše Mountains, Czech Republic. Permafrost Periglac. 2013;24:313-321. 
50. Treml V, Kř́žžek M, Engel Z. Classification of patterned ground based on morphology and site characteristics: a case study from the High Sudetes, Central Europe. Permafrost Periglac. 2010;21:67-77.

51. Ballantyne CK, Harris C. The Periglaciation of Great Britain. Cambridge: Cambridge University Press; 1994.

52. Ballantyne CK, Matthews JA. The Development of Sorted Circles on Recently Deglaciated Terrain, Jotunheimen, Norway. Arctic Alpine Res. 1982;14:341-354.

53. Cook JD. Active and relict sorted circles, Jotunheimen, Norway: a study of the altitudinal zonation of periglacial processes [dissertation] Cardiff: University of Wales; 1989.

54. Ellenberg L. Rezente Periglazialerscheinungen auf Cheju Dô, Südkorea. Geogr Helvetica. 1976;31:69-74.

55. Freund R. Die Kleinformen der Frostmusterböden: Vergleich Arktis - Alpen Tropisches Hochgebirge. Geogr Helvetica. 1971;26:142-147.

56. Furrer G. Die Strukturbodenformen der Alpen. Geogr Helvetica. 1955;10:193-213.

57. Gleason KJ, Krantz WB, Caine N, George JH, Gunn RD. Geometrical Aspects of Sorted Patterned Ground in Recurrently Frozen Soil. Science. 1986;232:216-220.

58. Grab SW. Annually re-forming miniature sorted patterned ground in the High Drakensberg, southern Africa. Earth Surf Proc Land. 1997;22:733-745.

59. Hallet B, Prestrud S. Dynamics of periglacial sorted circles in Western Spitsbergen. Quaternary Res. 1986;26:81-99.

60. Holness SD. Sorted circles in the maritime Subantarctic, Marion Island. Earth Surf Proc Land. 2003;28:337-347.

61. Humlum O, Christiansen HH. Mountain Climate and Periglacial Phenomena in the Faeroe Islands. Permafrost Periglac. 1998;9:189-211.

62. Kück KM. Periglacial features in the vicinity of Tiffindell ski resort, North East Cape Drakensberg, South Africa, and their implications for the development of the resort [dissertation]. Grahamstown: Rhodes University; 1996.

63. Ray RJ, Krantz WB, Caine TN, Gunn RD. A model for sorted patterned-ground regularity. J Glaciol. 1983;29:317-337.

64. Troll C. Strukturböden, Solifluktion und Frostklimate der Erde. Geol Rundsch. 1944;34:545-694.

65. Wilson P. Small-scale Patterned Ground, Comeragh Mountains, Southeast Ireland. Permafrost Periglac. 1992;3:63-70. 
66. Wilson P, Clark R. Development of Miniature Sorted Patterned Ground Following Soil Erosion in East Falkland, South Atlantic. Earth Surf Proc Land. 1991;16:369-376.

67. Love A. Patterned Ground at Beartooth Butte and East Summit, Wyoming: Geometry, Analysis, and Origin. In: Carson RJ, DeSimone D, Leonard EM, eds. Quaternary Geology of the Clarks Fork Region, Northwestern Wyoming and Adjacent Montana. Claremont, CA: Keck Geology Consortium; 1995:113-116.

68. Milsom J. Field Geophysics. Chichester: Wiley; 2003.

69. Heyman J, Applegate PJ, Blomdin R, Gribenski N, Harbor JM, Stroeven AP. Boulder height e exposure age relationships from a global glacial ${ }^{10} \mathrm{Be}$ compilation. Quat Geochronol. 2016;34:1-11.

70. Chmeleff J, von Blanckenburg F, Kossert K, Jakob D. Determination of the ${ }^{10}$ Be halflife by multicollector ICP-MS and liquid scintillation counting. Nucl Instrum Meth B. 2010;263:192-199.

71. Korschinek G, Bergmaier A, Faestermann T, et al. A new value for the half-life of ${ }^{10} \mathrm{Be}$ by heavy-ion elastic recoil detection and liquid scintillation counting. Nucl Instrum Meth B. 2010;268:187-191.

72. Braucher R, Guillou V, Bourlès DL, et al. Preparation of ASTER in-house ${ }^{10} \mathrm{Be} /{ }^{9} \mathrm{Be}$ standard solutions. Nucl Instrum Meth B. 2015;361:335-340.

73. Arnold M, Merchel S, Bourlès DL, et al. The French accelerator mass spectrometry facility ASTER: improved performance and developments. Nucl Instrum Meth B. 2010;268(11-12):1954-1959.

74. Borchers B, Marrero S, Balco G, et al. Geological calibration of spallation production rates in the CRONUS-Earth project. Quat Geochronol. 2016;31:188-198.

75. Stone JO. Air pressure and cosmogenic isotope production. J Geophys Res. 2000;105:23753-23759.

76. Dunne J, Elmore D, Muzikar P. Scaling factors for the rates of production of cosmogenic nuclides for geometric shielding and attenuation at depth on sloped surfaces. Geomorphology. 1999;27:3-11.

77. Gosse JC, Phillips FM. Terrestrial in situ cosmogenic nuclides: theory and application. Quaternary Sci Rev. 2001;20:1475-560.

78. Braucher R, Merchel S, Borgomano J, Bourlès DL. Production of cosmogenic radionuclides at great depth: a multi element approach. Earth Planet Sci Lett. 2011;309,1-9. 
79. Lal D. Cosmic ray labeling of erosion surfaces: in situ nuclide production rates and erosion models. Earth Planet Sci Lett. 1991;104:424-439.

80. Balco G. Glacier change and paleoclimate applications of cosmogenic-nuclide exposure dating. Annu Rev Earth Planet Sci. 2020;48:21-48.

81. Blomdin R, Stroeven AP, Harbor JM, et al. Evaluating the timing of former glacier expansions in the Tian Shan: A key step towards robust spatial correlations. Quaternary Sci Rev. 2016;153:78-96.

82. Engel Z, Braucher R, Traczyk A, et al. ${ }^{10}$ Be exposure age chronology of the last glaciation in the Krkonoše Mountains, Central Europe. Geomorphology. 2014;206:107121.

83. Engel Z, Braucher R, AsterTeam. Origin and ${ }^{10} \mathrm{Be}$ surface exposure dating of a coarse debris accumulation in the Hrubý Jeseník Mountains, central Europe. Geomorphology. 2020;365:107292.

84. Dunai TJ. Cosmogenic Nuclides. Cambridge: Cambridge University Press; 2010.

85. Phillips WM. A review of cosmogenic nuclide surface exposure dating: new challenges for Scottish geomorphology. Scott Geogr J. 2001;117:1-15.

86. Kessler MA, Murray AB, Werner BT, Hallet B. A model for sorted circles as selforganized patterns. J Geophys Res. 2001;106(B7):13287-13306.

87. French H. The Periglacial Environment. $4^{\text {th }}$ ed. Chichester: Wiley; 2018.

88. Sekyra J, Sekyra Z. Former existence of a plateau icefield in Bílá louka Meadow, eastern Giant Mountains: hypothesis and evidence. Opera Corcon. 2002;39:35-43.

89. Ludwig, P, Schaffernicht EJ, Shao Y, Pinto JG. Regional atmospheric circulation over Europe during the Last Glacial Maximum and its links to precipitation. J Geophys ResAtmos. 2016;121,2130-2145.

90. Knotek Z. Geologie Jizerských hor. In: Karpaš R, ed. Jizerské hory - O mapách, kamení $a$ vodě. Liberec: Knihy 555; 2009:104-141.

91. Guido ZS, Ward DJ, Anderson RS. Pacing the post-Last Glacial Maximum demise of the Animas Valley glacier and the San Juan Mountain ice cap, Colorado. Geology. 2007;35:739-742.

92. Prosová M. Studie o periglaciálních zjevech v Hrubém Jeseníku. Př́rodovědecký sborník Ostravského kraje. 1954;15:1-15.

93. Sekyra J. Působení mrazu na půdu - kryopedologie se zvláštním zřetelem k ČSR. Praha: Nakladatelství Československé Akademie Věd; 1960. 
94. Treml V, Jankovská V, Petr L. Holocene dynamics of the alpine timberline in the High Sudetes. Biologia. 2008;63:73-80.

95. Plug LJ, Gosse JC, McIntosh JJ, Bigley R. Attenuation of cosmic ray flux in temperate forest. J Geophys Res. 2007;112:F02022.

96. Antoine P, Coutard S, Guerin G, et al. Upper Pleistocene loess-palaeosol records from Northern France in the European context: Environmental background and dating of the Middle Palaeolithic. Quatern Int. 2016;411:4-24.

97. Moseley GE, Spötl C, Svensson A, Cheng H, Brandstätter S, Edwards RL. Multispeleothem record reveals tightly coupled climate between central Europe and Greenland during Marine Isotope Stage 3. Geology. 2014;42:1043-1046.

98. Agosta EA, Compagnucci RH. Abrupt Climate Changes During the Marine Isotope Stage 3 (MIS 3). In: Gasparini G, Rabassa J, Deschamps C, Tonni E, eds. Marine Isotope Stage 3 in Southern South America, 60 ka B.P.-30 ka B.P. Cham: Springer; 2016:81-106.

99. Rasmussen SO, Bigler M, Blockley S, et al. A stratigraphic framework for abrupt climatic changes during the Last Glacial period based on three synchronized Greenland ice-core records: refining and extending the INTIMATE event stratigraphy. Quaternary Sci Rev. 2014;106:14-28.

100. Seguinot J, Jouvet G, Huss M, Funk M, Ivy-Ochs S, Preusser F. Modelling last glacial cycle ice dynamics in the Alps. Cryosphere. 2018;12:3265-3285.

101. Engel Z, Nývlt D, Křížek M, Treml V, Jankovská V, Lisá L. Sedimentary evidence of landscape and climate history since the end of MIS 3 in the Krkonoše Mountains, Czech Republic. Quaternary Sci Rev. 2010;29:913-927.

102. Andrieux E, Bateman M, Bertran P. The chronology of Late Pleistocene thermal contraction cracking derived from sand wedge OSL dating in central and southern France. Glob Planet Change. 2018;162:84-100.

103. Woronko B, Zielinski P, Sokołowski RJ. Climate evolution during the Pleniglacial and Late Glacial as recorded in quartz grain morphoscopy of fluvial to aeolian successions of the European Sand Belt. Geologos. 2015;21:89-103.

104. Kovács J, Moravcová M, Újvári G, Pintér AG. Reconstructing the paleoenvironment of East Central Europe in the Late Pleistocene using the oxygen and carbon isotopic signal of tooth in large mammal remains. Quatern Int. 2012;276-277:145-154. 
105. Lowe JJ, Rasmussen SO, Bjorck S, et al. Synchronisation of palaeoenvironmental events in the North Atlantic region during the Last Termination: a revised protocol recommended by the INTIMATE group. Quaternary Sci Rev. 2008;27:6-17.

106. Lisiecki LE, Raymo MR. A Pliocene-Pleistocene stack of 57 globally distributed benthic d180 records. Paleoceanography. 2005;20:PA1003.

107. Clark PU, Dyke AS, Shakun JD, Carlson AE, Clark J, Wohlfarth B, Mitrovica JX, Hostetler SW, McCabe AM. The Last Glacial Maximum. Science. 2009;325(5941):710-713.

108. Juřičková L, Ložek V, Horáčková J, Tlachač P, Horáček I. Holocene succession and biogeographical importance of mollusc fauna in the Western Sudetes (Czech Republic). Quatern Int. 2014;353:210-224.

109. Alexandrowicz WP, Ciszek D, Gołas-Siarzewska M. Malacological characteristic of the Weichselian Upper Pleniglacial (MIS-2) loess profile in Tłumaczów (SW Poland). Geol Q. 2013;57(3):433-442.

110. Feurdean A, Perşoiu A, Tanţău I, et al. Climate variability and associated vegetation response throughout Central and Eastern Europe (CEE) between 60 and $8 \mathrm{ka}$. Quaternary Sci Rev. 2014;106:206-224.

111. Vandenberghe J, French HM, Gorbunov A, et al. The Last Permafrost Maximum (LPM) map of the Northern Hemisphere: permafrost extent and mean annual air temperatures, 25-17 ka BP. Boreas. 2014;43:652-666.

112. Růžičková E, Zeman A. The Blahutovice-1 borehole near Hranice na Moravě: weathering effects in Badenian deposits. Scripta Fac Sci Nat Univ Masaryk Brun Geol. 1992;22,128-132.

113. Žák K, Richter DK, Filippi M, et al. Coarsely crystalline cryogenic cave carbonate - a new archive to estimate the Last Glacial minimum permafrost depth in Central Europe. Clim Past. 2012;8:1821-1837.

114. Jahn A. The permafrost active layer in the Sudety Mountains during the last glaciation. Quaest Geogr. 1977;4:29-42.

115. Chmal H, Traczyk A. Plejstoceńskie lodowce gruzowe w Karkonoszach. Czas Geogr. 1993;64(3-4):253-262.

116. Waroszewski J, Kalinski K, Malkiewicz M, Mazurek R, Kozlowski G, Kabala C. Pleistocene-Holocene cover-beds on granite regolith as parent material for PodzolsAn example from the Sudeten Mountains. Catena. 2013;104:161-173. 
117. Traczyk A. Late Pleistocene Evolution of Periglacial and Glacial Relief in the Karkonosze Mountains. New Hypotheses and Research Perspectives. Acta U Carol Geogr. 2004;39:59-72.

118. Christensen NI, Mooney WD. Seismic velocity structure and composition of the continental crust: A global view. J Geophys Res. 1995;100(B6):9761-9788.

119. Small EE, Anderson RS, Repka JL, Finkel R. Erosion rates of alpine bedrock summit surfaces deduced from in situ ${ }^{10} \mathrm{Be}$ and ${ }^{26} \mathrm{Al}$. Earth Planet Sci Lett. 1997;150:413-425.

120. Portenga EW, Bierman PR, Rizzo DM, Rood DH. Low rates of bedrock outcrop erosion in the central Appalachian Mountains inferred from in situ ${ }^{10} \mathrm{Be}$. GSA Bulletin. 2013;125(1-2):201-215.

121. Crest Y, Delmas M, Braucher R, Gunnell Y, Calvet M, ASTER Team. Cirques have growth spurts during deglacial and interglacial periods: Evidence from ${ }^{10} \mathrm{Be}$ and ${ }^{26} \mathrm{Al}$ nuclide inventories in the central and eastern Pyrenees. Geomorphology. 2017;278:6077.

122. Dethier DP, Lazarus ED. Geomorphic inferences from regolith thickness, chemical denudation and CRN erosion rates near the glacial limit, Boulder Creek catchment and vicinity, Colorado. Geomorphology. 2006;75(3-4):384-399.

123. Refsnider KA. Dramatic increase in late Cenozoic alpine erosion rates recorded by cave sediment in the southern Rocky Mountains. Earth Planet Sci Lett. 2010;297:505-511.

124. Schaller M, Ehlers TA, Stor T, et al. Spatial and temporal variations in denudation rates derived from cosmogenic nuclides in four European fluvial terrace sequences. Geomorphology. 2016;274:180-192.

125. Migoń P, Danišík M. Erosional history of the Karkonosze Granite Massif - constraints from adjacent sedimentary basins and thermochronology. Geol Quart. 2012;56(3):440454.

126. Herman F, Seward D, Valla PG, et al. Worldwide acceleration of mountain erosion under a cooling climate. Nature. 2013;504:146-423. 
791 Table 1. Morphological characteristics and ${ }^{10} \mathrm{Be}$ surface exposure ages for sample boulders.

\begin{tabular}{|c|c|c|c|c|c|c|c|c|c|c|c|c|c|c|c|}
\hline Sample & Latitude $\left({ }^{\circ} \mathrm{N}\right)$ & Longitude $\left({ }^{\circ} \mathrm{E}\right)$ & $\begin{array}{l}\text { Altitude } \\
\text { (m a.s.l.) }\end{array}$ & $\begin{array}{l}\text { Boulder } \\
\text { length/width/he } \\
\text { ight }(\mathrm{m})\end{array}$ & \begin{tabular}{|l|} 
Surface \\
aspect /dip \\
$\left(^{\circ}\right)$
\end{tabular} & \begin{tabular}{|l|} 
Sam \\
ple \\
thick \\
ness \\
$(\mathrm{cm})$ \\
\end{tabular} & $\begin{array}{l}\text { Snow } \\
\text { depth/d } \\
\text { uration } \\
(\mathrm{cm} / \mathrm{m} \\
\text { onth) } \\
\end{array}$ & \begin{tabular}{|l} 
Total \\
shielding \\
factor
\end{tabular} & $\mid \begin{array}{l}\text { Productio } \\
\text { n rate } \\
\left(\mathrm{at}^{-1} \mathrm{~g}^{-1} \mathrm{yr}^{-1}\right)\end{array}$ & $\begin{array}{l}\text { 10Be concentration } \\
\text { (at-1g-1) }\end{array}$ & $\begin{array}{l}10 \mathrm{Be} \text { Age } \\
(\mathrm{yr})\end{array}$ & \begin{tabular}{|l} 
Analyti \\
cal \\
uncertai \\
nty \\
$( \pm$ yr) \\
\end{tabular} & $\begin{array}{l}\text { Total } \\
\text { uncertai } \\
\text { inty } \\
( \pm \mathrm{yr})\end{array}$ & i $\begin{array}{l}1{ }^{10} \text { Be max. } \\
\text { denudation rate } \\
(\mathrm{m} / \mathrm{My})\end{array}$ & $\begin{array}{l}\text { Integratio } \\
\text { n time (yr) }\end{array}$ \\
\hline VK-1 & 50.77646 & 15.56757 & 1506 & $2.2 / 0.6 / 0.6$ & $260 / 2$ & 2 & $80 / 6$ & 0.93035 & 12.93 & $377,555 \pm 14,199$ & 29,244 & 1100 & 2071 & $23.8 \pm 0.9$ & 29,032 \\
\hline VK-2 & 50.77648 & 15.56754 & 1503 & $1.3 / 0.3 / 0.5$ & $320 / 5$ & 5 & $80 / 6$ & 0.93035 & 12.90 & $288,275 \pm 10,354$ & 22,342 & 802 & 1562 & $31.4 \pm 1.1$ & 22,218 \\
\hline VK-3 & 50.77652 & 15.56754 & 1506 & $1.2 / 0.3 / 0.7$ & $295 / 6$ & 5 & $80 / 6$ & 0.93035 & 12.93 & $242,577 \pm 8922$ & 18,740 & 689 & 1319 & $37.5 \pm 1.4$ & 18,653 \\
\hline VK-4 & 50.77690 & 15.56740 & 1507 & $1.1 / 0.3 / 0.3$ & $330 / 10$ & 3 & $80 / 6$ & 0.93035 & 12.94 & $299,912 \pm 10,732$ & 23,177 & 829 & 1619 & $30.2 \pm 1.1$ & 23,044 \\
\hline VK-5 & 50.77691 & 15.56739 & 1506 & $0.8 / 0.3 / 0.2$ & $265 / 12$ & 3 & $80 / 6$ & 0.93035 & 12.93 & $367,295 \pm 14,630$ & 28,444 & 1133 & 2048 & $24.5 \pm 1.0$ & 28,243 \\
\hline VK-6 & 50.77686 & 15.56731 & 1507 & $1.5 / 0.3 / 0.2$ & $120 / 7$ & 6 & $80 / 6$ & 0.93035 & 12.94 & $391,981 \pm 14,423$ & 30,347 & 1117 & 2136 & $22.9 \pm 0.8$ & 30,118 \\
\hline LH-1 & 50.72779 & 15.68043 & 1545 & $0.8 / 0.6 / 0.3$ & $125 / 25$ & 6 & $80 / 6$ & 0.93034 & 13.32 & $1195,921 \pm 36,891$ & 91,318 & 2817 & 6161 & $7.3 \pm 0.2$ & 89,266 \\
\hline LH-2 & 50.72779 & 15.68046 & 1544 & $0.8 / 0.5 / 0.2$ & $0 / 0$ & 6 & $80 / 6$ & 0.93034 & 13.31 & $817,575 \pm 33,737$ & 62,023 & 2559 & 4517 & $10.9 \pm 0.5$ & 61,072 \\
\hline LH-3 & 50.72780 & 15.68053 & 1543 & $0.6 / 0.3 / 0.2$ & $195 / 8$ & 5 & $80 / 6$ & 0.93034 & 13.30 & $824,325 \pm 27,287$ & 62,592 & 2072 & 4289 & $10.8 \pm 0.4$ & 61,624 \\
\hline LH-4 & 50.72753 & 15.68201 & 1549 & $0.9 / 0.5 / 0.6$ & $325 / 3$ & 4 & $80 / 6$ & 0.93035 & 13.36 & $120,079 \pm 74,821$ & 8,955 & 5580 & 5606 & $79.3 \pm 49.4$ & 8936 \\
\hline LH-6 & 50.72749 & 15.68203 & 1546 & $0.9 / 0.6 / 0.3$ & $110 / 5$ & 3 & $80 / 6$ & 0.93035 & 13.33 & $803,916 \pm 30,423$ & 60,876 & 2304 & 4318 & $11.1 \pm 0.4$ & 59,959 \\
\hline BR-1 & 50.03324 & 17.18731 & 1354 & $0.8 / 0.2 / 0.6$ & $240 / 6$ & 3 & $55 / 6$ & 0.95101 & 12.01 & $455,811 \pm 18,923$ & 38,086 & 1581 & 2779 & $18.2 \pm 0.8$ & 37,726 \\
\hline BR-2 & 50.03330 & 17.18732 & 1355 & $1.4 / 0.4 / 0.5$ & $0 / 0$ & 4 & $55 / 6$ & 0.95101 & 12.02 & $347,730 \pm 12,938$ & 28,967 & 1078 & 2045 & $24.1 \pm 0.9$ & 28,758 \\
\hline BR-3 & 50.03324 & 17.18719 & 1354 & $0.7 / 0.2 / 0.4$ & $0 / 0$ & 5 & $55 / 6$ & 0.95101 & 12.01 & $272,835 \pm 10,804$ & 22,710 & 899 & 1633 & $31.0 \pm 1.2$ & 22,582 \\
\hline BR-4 & 50.03326 & 17.18737 & 1354 & $0.6 / 0.2 / 0.5$ & $0 / 0$ & 7 & $55 / 6$ & 0.95101 & 12.01 & $311,639 \pm 13,077$ & 25,961 & 1089 & 1901 & $27.0 \pm 1.1$ & 25,794 \\
\hline BR-5 & 50.03327 & 17.18739 & 1353 & $0.8 / 0.2 / 0.5$ & $0 / 0$ & 4 & $55 / 6$ & 0.95101 & 12.00 & $347,506 \pm 15,893$ & 28,994 & 1326 & 2187 & $24.1 \pm 1.1$ & 28,785 \\
\hline BR-6 & 50.03330 & 17.18739 & 1354 & $0.6 / 0.1 / 0.4$ & $0 / 0$ & 7 & $55 / 6$ & 0.95101 & 12.01 & $275,968 \pm 11,455$ & 22,972 & 954 & 1676 & $30.6 \pm 1.3$ & 22,841 \\
\hline VL-1 & 50.07115 & 17.26567 & 1266 & $1.6 / 0.4 / 1.7$ & $25 / 5$ & 5 & $50 / 5$ & 0.96271 & 11.46 & $234,005 \pm 9602$ & 20,392 & 837 & 1482 & $34.7 \pm 1.4$ & 20,288 \\
\hline VL-2 & 50.07105 & 17.26560 & 1267 & $1.1 / 0.5 / 0.7$ & $0 / 0$ & 5 & $50 / 5$ & 0.96271 & 11.39 & $542,127 \pm 15,768$ & 47,868 & 1392 & 3192 & $14.4 \pm 0.4$ & 47,300 \\
\hline
\end{tabular}




\begin{tabular}{|l|l|l|l|l|l|l|l|l|l|l|l|l|l|l|l|}
\hline VL-3 & 50.07115 & 17.26568 & 1266 & $1.8 / 0.4 / 1.5$ & $250 / 4$ & 4 & $50 / 5$ & 0.96271 & 11.33 & $201,218 \pm 7200$ & 17,718 & 634 & 1238 & $40.1 \pm 1.4$ & 17,640 \\
\hline VL-4 & 50.07096 & 17.26572 & 1266 & $1.9 / 0.3 / 0.9$ & $145 / 12$ & 6 & $50 / 5$ & 0.96271 & 11.38 & $187,172 \pm 7019$ & 16,411 & 615 & 1161 & $43.3 \pm 1.6$ & 16,344 \\
\hline VL-5 & 50.07095 & 17.26580 & 1266 & $0.9 / 0.4 / 0.7$ & $0 / 0$ & 6 & $50 / 5$ & 0.96271 & 11.39 & $270,860 \pm 9889$ & 23,773 & 868 & 1670 & $29.6 \pm 1.1$ & 23,632 \\
\hline VL-6 & 50.07091 & 17.26584 & 1266 & $0.9 / 0.2 / 0.6$ & $30 / 12$ & 6 & $50 / 5$ & 0.96271 & 11.33 & $224,345 \pm 8523$ & 19,764 & 751 & 1404 & $35.8 \pm 1.4$ & 19,667 \\
\hline
\end{tabular}


792 Table 2. Sample site characteristics and mean ${ }^{10} \mathrm{Be}$ exposure ages for patterned ground in the Sudetes 793 Mountains.

\begin{tabular}{|c|c|c|c|c|c|c|c|c|c|c|c|c|c|}
\hline \multirow[b]{2}{*}{ Site } & \multirow[b]{2}{*}{$\begin{array}{l}\text { Altitude } \\
\text { (m a.s.1.) }\end{array}$} & \multirow{2}{*}{$\begin{array}{l}\text { Mean/ } \\
\text { media } \\
\text { n slope } \\
\left(^{\circ}\right)\end{array}$} & \multirow{2}{*}{$\begin{array}{l}\text { Elevatio } \\
\text { n } \\
\text { relative } \\
\text { to local } \\
\text { tree line } \\
(\mathrm{m})\end{array}$} & \multirow{2}{*}{ Bedrock } & \multirow[b]{2}{*}{$\begin{array}{l}\text { Density } \\
\left(\mathrm{g} / \mathrm{cm}^{3}\right) \\
118\end{array}$} & \multirow[b]{2}{*}{$\begin{array}{l}\text { Mean } \\
\text { size of } \\
\text { polyg } \\
\text { on } \\
\text { bould } \\
\text { ers } \\
\text { (m) } \\
\end{array}$} & \multirow[b]{2}{*}{$\begin{array}{l}\text { Montane } \\
\text { ecosystem }\end{array}$} & \multirow[b]{2}{*}{ Vegetation } & \multirow[t]{2}{*}{$\chi 2_{R}$} & \multirow{2}{*}{$\begin{array}{l}\text { SD to } \\
\text { mean } \\
\text { expos } \\
\text { ure } \\
\text { age } \\
(\%)\end{array}$} & \multirow{2}{*}{\begin{tabular}{|l|} 
Age \\
cluster \\
ing \\
(class)
\end{tabular}} & \multicolumn{2}{|c|}{$\begin{array}{l}\text { Exposure Age } \pm \\
\text { uncertainty (kyr) }\end{array}$} \\
\hline & & & & & & & & & & & & Maximum & Mean \\
\hline $\begin{array}{l}\text { Vysoké } \\
\text { Kolo }\end{array}$ & $\begin{array}{l}1503- \\
1507\end{array}$ & $3 / 3$ & +128 & $\begin{array}{l}\text { fine-grained } \\
\text { biotite granite }\end{array}$ & 2.69 & 0.85 & tundra & $\begin{array}{l}\text { grasses, } \\
\text { lichens }\end{array}$ & 30.7 & 18 & $\mathrm{C}$ & $30.3 \pm 1.1$ & $25.4 \pm 1.9$ \\
\hline $\begin{array}{l}\text { Luční } \\
\text { hora }\end{array}$ & $\begin{array}{l}1543- \\
1549 \\
\end{array}$ & $3 / 2$ & +143 & quartzite & 2.65 & 0.23 & tundra & lichens & 97.2 & 52 & $\mathrm{C}$ & $91.3 \pm 2.8$ & $53.6 \pm 11.4$ \\
\hline $\begin{array}{l}\text { Břridličn } \\
\text { á hora }\end{array}$ & $\begin{array}{l}1353- \\
1355\end{array}$ & $4 / 4$ & +30 & $\begin{array}{l}\text { quartz-rich } \\
\text { phyllite }\end{array}$ & 2.73 & 0.75 & tundra & $\begin{array}{l}\text { grasses, } \\
\text { lichens, } \\
\text { dwarf } \\
\text { shrubs }\end{array}$ & 21.4 & 20 & $\mathrm{C}$ & $38.1 \pm 1.6$ & $27.9 \pm 2.3$ \\
\hline $\begin{array}{l}\text { Větrná } \\
\text { louka }\end{array}$ & $\begin{array}{l}1266- \\
1267\end{array}$ & $3 / 3$ & -87 & $\begin{array}{l}\text { quartz-rich } \\
\text { phyllite }\end{array}$ & 2.73 & 1.17 & forest & $\begin{array}{l}\text { spruce } \\
\text { forest }\end{array}$ & 123.8 & 49 & C & $47.9 \pm 1.4$ & $24.3 \pm 4$ \\
\hline
\end{tabular}

795 Table 3. Morphology of patterned ground at sample sites.

\begin{tabular}{|llllllllll|}
\hline Site & $\begin{array}{l}\text { Altitude } \\
(\mathrm{m} \text { a.s.1.) }\end{array}$ & $\begin{array}{l}\text { Mean } \\
\text { length } \\
(\mathrm{m})\end{array}$ & $\begin{array}{l}\text { Mean } \\
\text { width } \\
(\mathrm{m})\end{array}$ & $\begin{array}{l}\text { Mean } \\
\text { height } \\
(\mathrm{m})\end{array}$ & $\begin{array}{l}\text { Width/Length } \\
\text { index }\end{array}$ & $\begin{array}{l}\text { Min-Max } \\
\text { Length }\end{array}$ & $\begin{array}{l}\text { Min-Max } \\
\text { Width }\end{array}$ & $\begin{array}{l}\text { Min-Max } \\
\text { Height }\end{array}$ & $N$ \\
\hline Vysoké Kolo & $1503-15076.97$ & 4.33 & 0.27 & 0.64 & $3.80-10.50$ & $2.50-6.00$ & $0.22-0.34$ & 9 \\
\hline Luční hora & $1543-15493.67$ & 3.01 & 0.11 & 0.83 & $2.50-5.60$ & $2.10-5.40$ & $0.00-0.30$ & 32 \\
\hline Břidličná hora & $1353-13555.05$ & 3.88 & 0.19 & 0.79 & $3.20-9.40$ & $2.70-6.40$ & $0.05-0.45$ & 32 \\
\hline Větrná louka & $1266-12674.76$ & 4.26 & 1.06 & 0.91 & $2.50-6.80$ & $2.30-6.00$ & $0.50-1.50$ & 8 \\
\hline
\end{tabular}

796

797

798

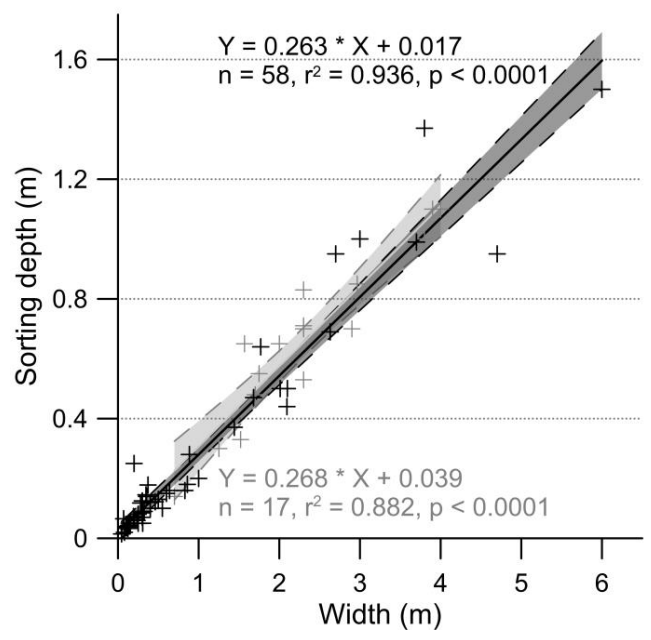

800 Figure 4. Width of sorted patterned ground 801 used to estimate the active-layer thickness.

802 Black crosses, solid and dashed black lines 803 indicate the data (from ${ }^{5,51-66}$ ), linear fit 804 and $95 \%$ confidence intervals for active 805 forms. Relict sorted polygons and circles 806 (grey symbols; data from ${ }^{4,9,63,67}$ ) reveal 807 very similar relationship between width 808 and sorting depth confirming that these 809 forms are indicative of active layer. 

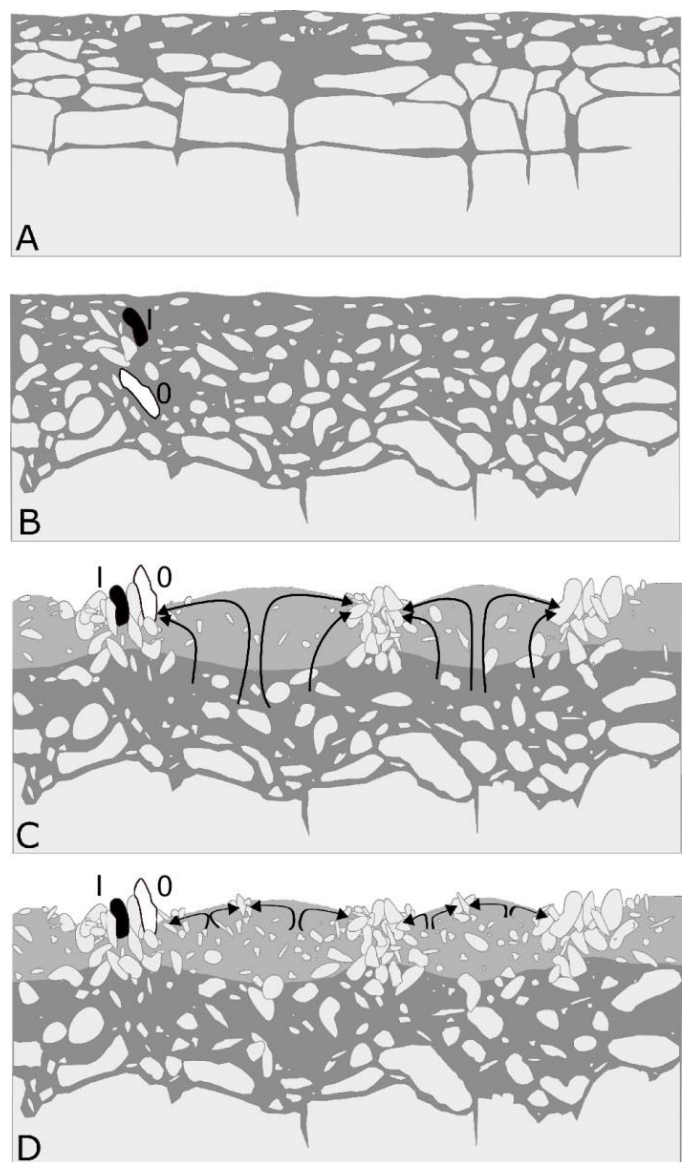

Figure 8. Concept of large sorted polygon formation: regolith formation (A), onset of differential frost heave and buoyancy-driven clast circulation (B), well-developed forms composed of frost-heaved and laterally sorted boulders and finer clasts in the centre $(C)^{1,86}$, formation of small sorted patterns in the fine domain of large sorted polygons (D). Dark and light grey colours show a regolith matrix and the central fine domain of polygons, respectively. $I$ and 0 mark the location of boulders with inherited nuclide component and zero inheritance, respectively. Arrows indicate motion of clasts within the fine domain. 